Article

\title{
Investigating the Potential of Radar Interferometry for Monitoring Rural Artisanal Cobalt Mines in the Democratic Republic of the Congo
}

\author{
Chloe Brown ${ }^{1,2, *}$, Anna Daniels ${ }^{1}\left(\mathbb{C}\right.$, Doreen S. Boyd $\left.{ }^{1,2}{ }^{(}\right)$, Andrew Sowter ${ }^{3,4}$, Giles Foody ${ }^{1,2}$ (D) \\ and Siddharth Kara ${ }^{2,5}$ \\ 1 School of Geography, University of Nottingham, Nottingham NG7 2RD, UK; \\ anna.daniels@hotmail.co.uk (A.D.); doreen.boyd@nottingham.ac.uk (D.S.B.); \\ giles.foody@nottingham.ac.uk (G.F.) \\ 2 Rights Lab, University of Nottingham, Nottingham NG7 2RD, UK; Siddharth.Kara@nottingham.ac.uk \\ 3 Nottingham Geospatial Institute, University of Nottingham, Nottingham NG7 2TU, UK; \\ andrew.sowter@terramotion.co.uk \\ 4 Terra Motion Limited, Ingenuity Centre, Nottingham NG7 2TU, UK \\ 5 School of Sociology and Social Policy, University of Nottingham, Nottingham NG7 2RD, UK \\ * Correspondence: Chloe.Brown1@nottingham.ac.uk
}

Received: 28 September 2020; Accepted: 18 November 2020; Published: 24 November 2020

\begin{abstract}
Greater awareness of the serious human rights abuses associated with the extraction and trade of cobalt in the Democratic Republic of the Congo (DRC) has applied increasing pressure for businesses to move towards more responsible and sustainable mineral sourcing. Artisanal and small-scale mining (ASM) activities in rural and remote locations may provide heightened opportunities to conceal the alleged human rights violations associated with mining, such as: hazardous working conditions, health impacts, child labour, child trafficking, and debt bondage. In this study, we investigate the feasibility of the Intermittent Small Baseline Subset (ISBAS) interferometric synthetic aperture radar (InSAR) method, teamed with high temporal frequency Sentinel-1 imagery, for monitoring ASM activity in rural locations of the "Copperbelt", the DRC. The results show that the ISBAS descriptive variables (mean, standard deviation, minimum, and maximum) were significantly different ( $p$-value $=\leq 0.05$ ) between mining and non-mining areas. Additionally, a significant difference was found for the ISBAS descriptive variables mean, standard deviation, and minimum between the different mine types (industrial, surface, and tunnels). As expected, a high level of subsidence (i.e., negative ISBAS pixel value) was a clear indicator of mine activity. Trial activity thresholds were set for the descriptive variables mean $(-2.43 \mathrm{~mm} / \mathrm{yr})$ and minimum $(-5.36 \mathrm{~mm} / \mathrm{yr})$ to explore an ISBAS approach to active mine identification. The study concluded that the ISBAS method has great potential as a monitoring tool for ASM, with the ability to separate mining and non-mining areas based on surface motion values, and further distinguish the different mine types (industrial, surface, and tunnel). Ground data collection and further development of ISBAS analysis needs to be made to fully understand the value of an ISBAS-based ASM monitoring system. In particular, surrounding the impact of seasonality relative to longer-term trends in ASM activity.
\end{abstract}

Keywords: cobalt; sustainable mining; surface motion; Copperbelt; Intermittent Small BAaseline Subset (ISBAS); InSAR; Sentinel-1

\section{Introduction}

The increasing demand for rechargeable batteries to power the necessities of modern life, such as smartphones, laptops, and electric vehicles, has resulted in a chaotic scramble for cheap materials in 
the world's largest known copper/cobalt reserve (in the Democratic Republic of the Congo (DRC)). Reports from non-government organisations (NGOs) and media outlets [1-7] have sparked outrage over the alleged serious injustices associated with the extraction and trade of cobalt in the DRC, including: hazardous working conditions, child labour, child trafficking, debt bondage, and health and environmental impacts. Such injustices map onto a number of United Nations (UN) Sustainable Development Goals (SDGs), most notably SDG 8: Decent Work and Economic Growth and SDG 16: Peace, Justice and Strong Institutions. There is also a growing level of concern over potential conflicts in striving to address the SDGs surrounding "green conflict minerals" such as cobalt [8]. Efforts to step into low-carbon economies to meet SDG 7: Affordable and Clean Energy and SDG 13: Climate Action, via cobalt, contradict the targets of other SDGs. Thus, it is essential that responsible and sustainable sourcing practices are secured in "green conflict mineral" supply chains, in order to achieve the UN SDGs by 2030.

The DRC produces an estimated $50 \%-70 \%$ of global cobalt supply in a region known as the "Copperbelt", an area of concentrated copper/cobalt deposits that extends from southern DRC to northern Zambia. Cobalt mining in the DRC is divided into two distinct categories: large-scale mining (LSM) and artisanal and small-scale mining (ASM). LSM is the main producer of cobalt in the DRC, comprising $70 \%-80 \%$ of total production while ASM represents the remaining $20 \%-30 \%$ [9]. The exact percentage breakdown of LSM and ASM output is a topic of debate, a lack of credible material traceability, and ASM's role as a "swing producer" to meet fluctuating supply and demand, mean reported ASM/LSM estimates can vary widely. Unlike industrial LSM, ASM adopts a rudimental, labour-intensive form of mineral exploration, extraction, and processing with minimal to no oversight, regulation, and safety measures. Poverty and a lack of alternative employment have "pushed" miners into working under increasingly unsafe and economically unstable employment [10,11]. Furthermore, child labour is widespread in ASM [12-14]. Away from the major cities (Lubumbashi, Likasi, and Kolwezi) and towns of the Copperbelt, large areas of land cover a more remote and rural setting. This remote mountainous landscape may provide heightened opportunities to conceal the serious abuses associated with cobalt ASM practices in the DRC. Kara's fieldwork [15], documented 31 ASM locations in the Copperbelt. Some of these sites were previously undocumented and tended to be situated in the remote mountains near the Zambian border. Estimates for workers involved in ASM practices vary widely [9], where discrepancy between estimates results from the questionable legal status and seasonality, by the fluctuating international market and calendar year, of ASM. Additional uncertainty stems from a lack of data for ASM activity in rural and remote settings as these tend to be "hidden".

From a "responsible" supply chain management standpoint, sourcing cobalt from LSM is often presented as a viable measure to avoid the human rights risks which are considered to be more prevalent in ASM. However, there is extensive interactions between LSM and ASM from production through to supply. Despite the "cleaner" perception of LSM, a significant number of LSM operators, processors, and refiners source and blend ASM material with those of LSM [9]. Kara's research discovered many workers involved in ASM activates were also working on LSM sites with tacit approval of mining companies. Lack of reliable information or traceability of source materials has made it highly likely that cobalt derived for ASM has entered global supply chains as LSM [16]. Increasing customer and stakeholder awareness of the human rights abuses associated with sourcing cobalt from the DRC has applied pressure for businesses to prove responsible and sustainable activity throughout their supply chains [17].

In December 2019, a US lawsuit based on Kara's research named several large tech companies, such as Apple, Google, Microsoft, Dell, and Tesla, as knowingly sourcing cobalt mined by children at various sites under dangerous conditions that ultimately led to serious injury and death [18]. In response to this legal challenge, several of the named companies have restated their commitment to work against human rights abuses in their supply chains, opting to halt all sourcing of cobalt from ASM in the DRC. However, for many, including China's biggest cobalt producer Huayou Cobalt, this halting is just a temporary measure "until relevant standards can be recognised and supported by 
the whole industry" (Huayou Cobalt statement) [19]. Many, such as Mark Dummet, head of business, security and human rights at Amnesty International, have criticised this direct approach, saying "We need to see companies working with the authorities to formalise 'the ASM cobalt sector' - make it safer, remove children, provide miners with a fair price. By refusing to buy from artisanal miners, Huayou risks making the situation for these miners worse, not better." [19].

In early 2020, the DRC government announced a new formalisation of ASM in a bid to take charge and improve the country's cobalt sector. A new State-run company, named Entreprise Generale du Cobalt (overseen by Gecamines), has been granted monopoly powers to purchase and market all ASM cobalt outputs. It is hoped that this new purchasing power will allow greater State oversight of working conditions in the ASM sector, prioritising the elimination of child labour and improved safety measures. This move has been branded as an effort to clean up supply chains dominated by Chinese traders and support the price of cobalt in a fluctuating market [20]. Through NGOs, the Entreprise Generale du Cobalt selects ASM cooperatives based on their compliance to responsible sourcing criteria. Those that do not meet the criteria will be "sanctioned", although what these sanctions may look like remains unclear [21]. Increased State control might be a welcome development for the cobalt market; however, the country's history of weak governance and grand corruption poses a serious risk to the responsible management of a formalised ASM sector. It must also be asked, how far will these new government efforts work towards formalising ASM in rural and remote settings? Undocumented ASM sites operate undetected and unregulated in the Copperbelt's densely forested and mountainous landscape. Thus, a major data gap lies in our knowledge of the scale and impact of ASM activity, particularly in remote and rural locations.

Satellite Earth Observation (EO) has been flagged as a practical and informative data source in tackling the diverse range issues addressed by the SDGs [22-24]. Recently, a growing number of studies have applied a range of EO technologies and data to explore SDG targets and indicators related to human rights violations [25-28]. In this paper, we focus on satellite radar interferometry as a technology suitable for providing data on ASM activity in the DRC. Radar interferometry is a well-established EO technique for monitoring surface motion $[29,30]$ and has been widely applied in the mining sector [31-33]. Differential interferometric synthetic aperture radar (DInSAR) is a method that measures the difference in the recorded phase from two synthetic aperture radar (SAR) images acquired over the same region of the Earth's surface at different times. Teamed with state-of-the-art satellite constellations, such as the European Space Agency's Sentinel-1, this method has the capacity to repeatedly monitor surface motion at millimetre precision over large areas, including areas inaccessible by fieldwork due to access issues or safety risks. The integration of DInSAR and Global Positioning System (GPS) measurements has been previously trailed as a monitoring tool for underground mine-induced surface subsidence. Yuan et al. [34] and Hu et al. [35] both investigated this approach for illegal coal mine detection, producing encouraging results over case study areas in Asia. Hu et al. [35], in particular, demonstrated the efficiency and reliability of a DInSAR-based method for extracting key information on the geometric, spatial, and temporal characteristics of mine and illegal mine subsidence. An advanced DInSAR processing technique, the Intermittent Small BAseline Subset (ISBAS) method [36], has been increasingly utilised in rural and densely vegetated landscapes, areas which are often challenging for DInSAR algorithms as a result of low coherence [37]. The development of the ISBAS method has proved useful in investigating surface motion in various applications including: groundwater rebound and abstraction [38], oil and gas production and storage [39,40], landslides [41], and monitoring peatland in temperate and tropical environments [42-45]. Notably, the ISBAS method has been previously used in mining applications, predominantly in coalfields found in the United Kingdom (UK) [36,46-49]. Gee et al. [46] applied the ISBAS method to ERS (European Remote Sensing), ENVISAT (Environmental Satellite), and Sentinel-1 SAR datasets covering the time periods of the late 1990s, the 2000s, and the mid-2010 s, respectively, over the Northumberland and Durham coalfield, UK. The study reported regional patterns of uplift present in the ISBAS derived outputs from all three datasets, often occurring in previously mined areas. The uplift was attributed to 
the increase in pore water pressure after mine closure; however, it was recognised that further work is required to fully understand the degree of influence rising mine water has on ground surface motion. Localised subsidence was also identified over former mines during the late 1990s, with subsidence hotspots detected in close proximity to former mining infrastructure. Bateson et al. [47] implemented the ISBAS method on ERS data for the time period 1992-1999 over the South Wales coalfield, UK. The results presented broad areas of uplift from the derived ISBAS outputs; again this was associated with groundwater rebound following the removal of mining infrastructure and pumping activity associated with mine closure. Both investigations highlight the complexity of a post-mining landscape, in particular the interactions between surface motion and the subsurface environment, and the benefit of the ISBAS method in characterising these.

When pairs of SAR images are used to form an interferometric pair, the coherence, or complex correlation, between the images, can be a good indication of change. A coherence analysis has already been used to good effect to identify changes relating to illegal open-pit mining over a relatively arid, sparsely vegetated site [50]. However, rural areas of the DRC's Copperbelt are dominated by thick vegetation, which, because of its association with very low coherence, would likely preclude a similar type of analysis for cobalt mining. Land subsidence is a clear indicator of underground and surface mining activity and, therefore, high-resolution monitoring of surface motion through satellite EO data has the potential to provide key insights into cobalt ASM dynamics. The aim of this study is thus to investigate the feasibility of using the ISBAS method, already proven to work in challenging environments, teamed with high temporal frequency Sentinel-1 imagery, for monitoring ASM activity in rural and remote locations of the Copperbelt in the DRC using subsidence as the indicator. To the best of our knowledge, this is the first peer-reviewed study regarding the application of the ISBAS (or any related InSAR) method to a cobalt mining environment. The complex surface movements and subsidence patterns produced from different types of cobalt mining-industrial mining (LSM), surface mining (ASM) and tunneling (ASM) — combined with the humanitarian issues associated with DRC's ASM sector, create a novel and indeed worthy landscape to investigate the application of the ISBAS method. In this study, we ask the question: can the ISBAS approach be used to identify active areas of ASM in a rural landscape? Data resources, such as reliable ASM monitoring systems, are required to inform and support positive reforms to workers' rights [51] and work towards meeting SDG targets [52]. However, past experience of the DRC's fragile governance and grand corruption suggests there is no guarantee that the data will not be used nefariously. As a result, we will not publish specific geographical information (i.e., coordinates) of the study area to protect vulnerable people and communities at risk of further harm.

\section{Materials and Methods}

\subsection{Study Area}

The study focuses on a large rural area $\left(>6000 \mathrm{~km}^{2}\right)$ in the heart of the Copperbelt: between the cities Kolwezi and Lubumbashi, the respective capitals of Lualaba and Haut-Katanga provinces, DRC (Figure 1). The region's subtropical climate is characterised by two distinct seasons, rainy (November-April) and dry (May-October). With a mean annual temperature of $20^{\circ} \mathrm{C}$ and a mean annual rainfall of $1300 \mathrm{~mm}$ (the majority $(1200 \mathrm{~mm}$ ) of which falls during the rainy season). The dominant natural vegetation is open deciduous Miombo woodland, with herbaceous vegetation covering the prominent steep copper/cobalt hills [53]. Miombo woodland has a rich fauna and flora and is essential in providing goods and services to support local rural livelihoods [54]. Local employment centres on mining (Figures 2 and 3) and subsistence farming activities. 


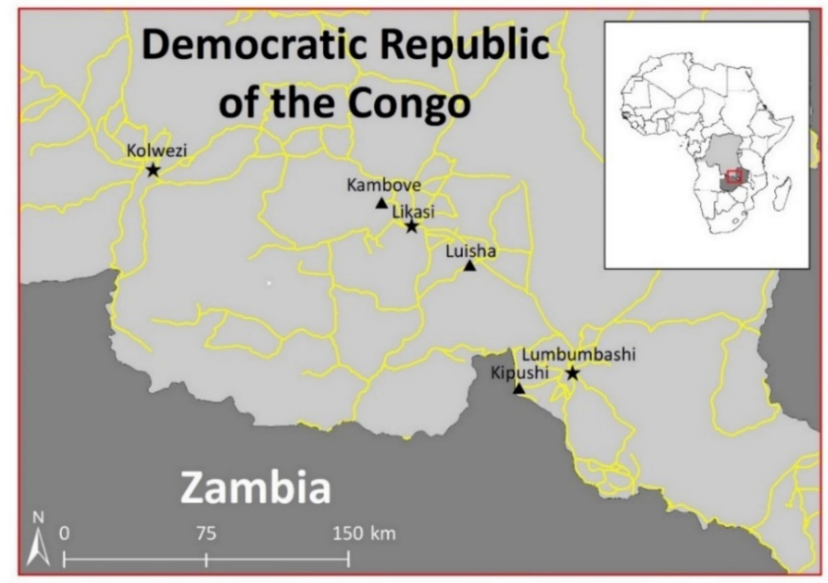

Figure 1. Map of the "Copperbelt" with the location of the major cities and townships. Yellow line represents the road network.

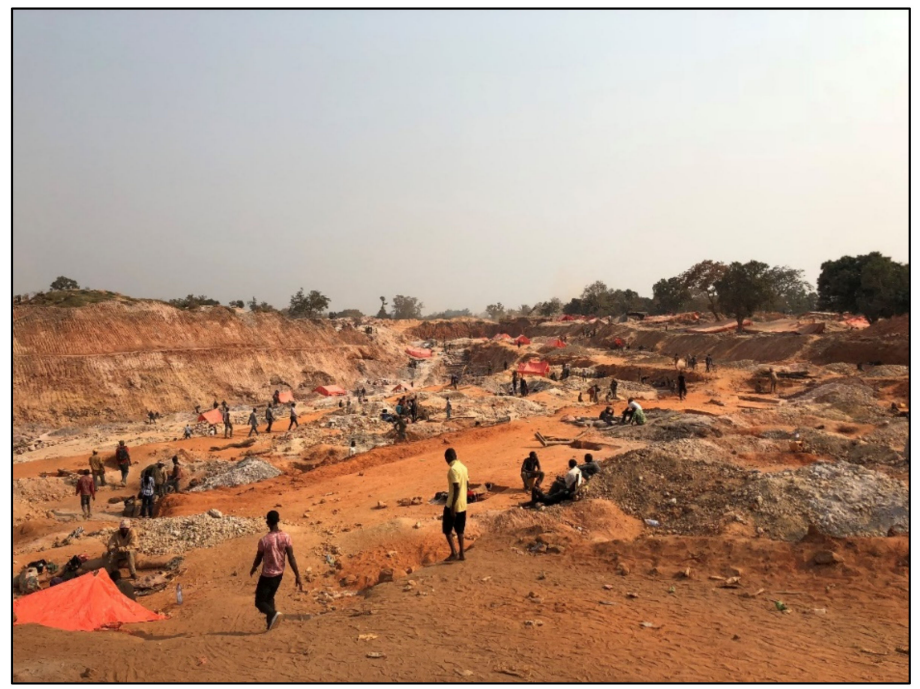

Figure 2. Cobalt mining site near Kasulo. Photograph: Siddharth Kara.

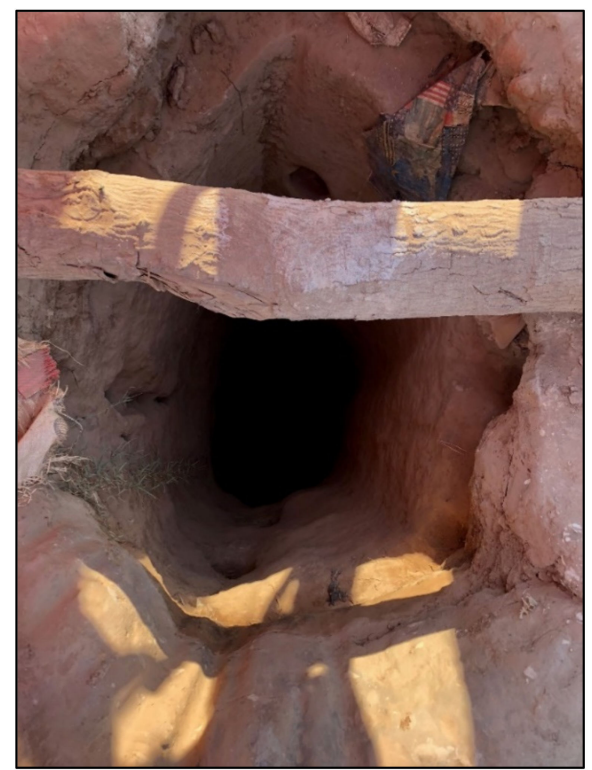

Figure 3. Cobalt tunnel mine. Photograph: Siddharth Kara. 
Copper/cobalt concentrations vary across the study area, with large clusters of mining activity featured around established deposits, as well as isolated examples of mineral exploration and extraction. Cobalt mining in the DRC forms two distinct sectors: LSM and ASM (Tables 1 and 2).

Table 1. Summary of the defining features of large-scale (LSM) and artisanal and small-scale (ASM) cobalt mining, including the mining operations and negative associations.

\begin{tabular}{|c|c|c|c|}
\hline LSM/ASM & Mine Type & Mining Operations & Negative Associations \\
\hline LSM & Industrial & $\begin{array}{l}\text { - long-term operations } \\
\text { - high capital investment } \\
\text { - uniform, terraced platform pit structure } \\
\text { - use large machinery and a high degree } \\
\text { of mechanisation and automation } \\
\text { (surface scrapers, bulldozers, and diggers) } \\
\text { - often operator, processor, and refiner sit in } \\
\text { the same mining complex (high proportion of } \\
\text { industrial buildings and infrastructure) }\end{array}$ & $\begin{array}{l}\text { - bribery and corruption } \\
\text { - money laundering } \\
\text { - tax evasion }\end{array}$ \\
\hline ASM & Surface & $\begin{array}{l}\text { - low capital investment } \\
\text { - open pit, irregular surface texture (lunar) } \\
\text { - labour intensive, rudimentary tools } \\
\text { (shovels, chisels, and mallets) } \\
\text { and handpicking (mineral sorting) } \\
\text { - varying levels of formalisation (permits) }\end{array}$ & $\begin{array}{l}\text { - hazardous working conditions } \\
\text { - alcohol abuse } \\
\text { - child labour } \\
\text { - child trafficking } \\
\text { - debt bondage (high degree of dependency } \\
\text { on sponsors) } \\
\text { - violence and extortion by security forces }\end{array}$ \\
\hline ASM & Tunnel & $\begin{array}{l}\text { - seasonal work (calendar year } \\
\text { and cobalt price) } \\
\text { - low capital investment } \\
\text { - underground tunnels up to } 30 \mathrm{~m} \text { deep } \\
\text { - dug with shovels, chisels, and mallets } \\
\text { - tunnel structure supported by wooden } \\
\text { stakes linebreak } \bullet \text { vary in number from } 10 \mathrm{~s} \\
\text { to } 100 \mathrm{~s} \text { in one location }\end{array}$ & $\begin{array}{l}\text { - hazardous working conditions } \\
\text { - alcohol abuse } \\
\text { - child labour } \\
\text { - child trafficking } \\
\text { - debt bondage (high degree of dependency } \\
\text { on sponsors) } \\
\text { - violence and extortion by security forces }\end{array}$ \\
\hline
\end{tabular}

Table 2. Surface motion characteristics (subsidence and uplift) of large-scale (LSM) and artisanal and small-scale (ASM) cobalt mining.

\begin{tabular}{|c|c|c|c|}
\hline \multirow{2}{*}{ LSM/ASM } & \multirow{2}{*}{ Mine Type } & \multicolumn{2}{|c|}{ Surface Motion Characteristics: } \\
\hline & & Subsidence & Uplift \\
\hline LSM & Industrial & $\begin{array}{l}\text { - a high volume of rock material removal } \\
\text { - creation of terrace structure } \\
\text { - exploration of new deposits } \\
\text { - exploration of deeper deposits }\end{array}$ & $\begin{array}{l}\text { - rock material pilling } \\
\text { - halt in activity or abandonment of pit } \\
\text { - development of infrastructure }\end{array}$ \\
\hline ASM & Surface & $\begin{array}{l}\text { - landslides } \\
\text { - mineral extraction } \\
\text { - exploration of new deposits } \\
\text { - removal of vegetation }\end{array}$ & $\begin{array}{l}\text { - rock material pilling } \\
\text { - seasonality } \\
\text { - halt in activity or abandonment of pit }\end{array}$ \\
\hline ASM & Tunnel & $\begin{array}{l}\text { - tunnel collapse } \\
\text { - vertical and horizontal digging } \\
\text { - groundwater level movement } \\
\text { - mineral extraction } \\
\text { - exploration of new deposits } \\
\text { - removal of vegetation }\end{array}$ & $\begin{array}{l}\text { - rock material pilling } \\
\text { - seasonality } \\
\bullet \text { halt in activity or abandonment of tunnel }\end{array}$ \\
\hline
\end{tabular}

\subsection{Sentinel-1 ISBAS Processing}

Eighty-two Sentinel-1 Interferometric Wide Swath Single Look Complex (Level 1) images along descending track 94 were used over our area of interest (AOI). All images were downloaded from the Copernicus Open Access Hub (https://scihub.copernicus.eu/). Our AOI was divided into two tiles, hereby know as North tile and South tile. SAR images were acquired for the time frame 6/3/2017 to 26/1/2020. This time frame marks a dynamic period in the DRC's cobalt mining sector, with demand and price skyrocketing up to a peak in 2018 and steadily falling to present levels by mid-2019. Additionally, this longer time frame was selected to provide sufficient frames for ISBAS processing [47]. 
Images were processed using the modified ISBAS processing chain for Sentinel-1, as outlined by Sowter et al. [36,38], to produce vertical surface motion mapping. This method maximises coverage in rural and vegetated areas compared with alternative DInSAR processing techniques [55] by permitting pixels of variable coherence to be considered alongside those with consistently high coherence [38,47]. This advantage was critical, as our AOI is highly vegetated (forest and agriculture) and experiences intense seasonal variability (rainy and dry seasons). ISBAS processing sets a threshold of average coherence at 0.45 to identify coherent pixels. From the coherent pixels identified, 1651 interferograms were produced from the Sentinel-1 images, with a temporal baseline of 365 days and a geometric baseline set to $100 \mathrm{~m}$. Topographic phase was removed from the interferograms with the aid of the $90 \mathrm{~m}$ Shuttle Radar Topography Mission (SRTM) digital elevation model [56]. The resulting differential interferograms were subsequently subjected to multi-looking to reduce the correlation coefficient used in the calculation of coherence. Each coherent pixel was unwrapped in relation to a reference pixel using a statistical-cost network-flow algorithm [57], and the line-of-sight (LOS) velocity and error calculated by regression analysis. Vertical velocity was calculated for each pixel through a simple trigonometric transformation from the LOS to generate a deformation (surface motion) map with a $20 \mathrm{~m}$ spatial resolution. The percentage of "NA" pixels (i.e., missing data) was calculated for the North and South tile outputs.

\subsection{Mine Identification}

Mines were visually identified in very high resolution (VHR) satellite imagery within the Google Earth platform. Identification was guided by expert knowledge gained from extensive fieldwork in the DRC's Copperbelt. A database of all mines identified within the boundaries of the North and South tile was created, with mines categorised as Industrial, Surface, or Tunnel (Table 3). Data collected for each mine included: identification number, coordinates, digitised polygon, polygon area $\left(\mathrm{m}^{2}\right)$, mine type, and date of the first appearance in the VHR imagery held in Google Earth.

Table 3. Summary of the visual features used to identify the different mine types on Google Earth.

\begin{tabular}{|c|c|c|}
\hline \multicolumn{3}{|c|}{ Visual Features } \\
\hline $\begin{array}{l}\text { - uniform, terraced platform } \\
\text { pit structure } \\
\text { - steep slopes } \\
\text { - large industrial complexes } \\
\text { - a high proportion of industrial } \\
\text { buildings and infrastructure } \\
\text { - often walled off from } \\
\text { surrounding areas }\end{array}$ & $\begin{array}{l}\text { - open pit, irregular surface texture } \\
\text { (lunar) } \\
\text { - crevasse and craters created from } \\
\text { the constant removal and scraping } \\
\text { of rock } \\
\text { - vary in size } \\
\text { - often found adjacent to industrial } \\
\text { LSM complexes } \\
\text { - often found near bodies of water for } \\
\text { washing and sorting purposes }\end{array}$ & $\begin{array}{l}\text { - tunnel hole between } 1-2 \mathrm{~m} \text { in diameter } \\
\text { - pink tarp tents (covering tunnel hole) } \\
\text { - vary in numbers from } 10 \mathrm{~s} \text { to } 100 \mathrm{~s} \text { in } \\
\text { one location } \\
\text { - often found adjacent to industrial } \\
\text { LSM complexes }\end{array}$ \\
\hline
\end{tabular}

This approach might be limited by the availability of VHR data in Google Earth. The spatial and temporal availability of satellite data in Google Earth varies globally [58], as this is based on satellite coverage and agreements with data providers. Throughout our search of the Google Earth archives, areas with little VHR data available were noted and referred back to in data interpretation.

\subsection{Statistical Analysis}

The 'sp' and 'rgdal' packages for R (version 3.6.3) were used to generate a random sample set of non-mine locations within the North and South tile boundary, thus creating a non-mine dataset. The non-mine dataset matched the mine dataset by sample number and polygon area $\left(\mathrm{m}^{2}\right)$ distribution. Polygons from the mine and non-mine datasets were used to extract descriptive variables-mean, standard deviation, minimum, and maximum—from the ISBAS outputs for statistical analysis. 
The Wilcoxon test was used to determine if there were statically significant differences in the ISBAS descriptive variables (mean, standard deviation, minimum, and maximum) between mine and non-mine polygons. The Kruskal test and Pairwise Wilcoxon test (with Bonferroni adjustment to correct for familywise error in the Kruskal-Wallis tests) were used to determine if there were statically significant differences ( $p$-value $=\leq 0.05$ ) in the ISBAS descriptive variables (mean, standard deviation, minimum, and maximum) between the different mine types (industrial, surface, and tunnels). All statistical analysis was conducted in R software (version 3.5.2).

\subsection{ASM Activity}

Based on the results from the statistical analysis of the ISBAS descriptive variables (mean, standard deviation, minimum, and maximum) between mine and non-mine polygons, an activity threshold was set to identify active ASM (surface and tunnel) sites during the study time period, 6/3/2017 to 26/1/2020. A conservative activity threshold was set as a trail for exploring this approach, with the hope that future ground data collection and development of this technique will produce a more tailored and nuanced understanding of ASM surface motion patterns.

\section{Results}

\subsection{ISBAS Surface Motion Outputs}

The Sentinel-1 derived ISBAS surface motion outputs attained good spatial coverage across the study area (over land), given the rural landscape and mountainous terrain. The ISBAS results cover more than $91 \%$ of the pixels in the North tile and more than $95 \%$ of the pixels in the South tile (Table 4).

Table 4. A comparison of missing data (NA pixels) for the Sentinel-1 derived ISBAS surface motion North and South tile outputs.

\begin{tabular}{cccc}
\hline Tile & Total Number of Pixels & Number of NA Pixels & Percentage of NA Pixels \\
\hline North & $12,792,848$ & $1,066,479$ & $8.3 \%$ \\
South & $6,466,246$ & 313,431 & $4.8 \%$ \\
\hline
\end{tabular}

Surface motion maps and histograms for the North and South tile (Figure 4) illustrate the spatial distribution of surface motion for the time period 6/3/2017 to 26/1/2020. Negative values indicate subsidence and positive values uplift. ISBAS values range from $-17.69 \mathrm{~mm} / \mathrm{yr}$ to $+8.31 \mathrm{~mm} / \mathrm{yr}$ with an average pixel value of $-1.87 \mathrm{~mm} / \mathrm{yr}$ across the North tile, and $-7.91 \mathrm{~mm} / \mathrm{yr}$ to $+4.55 \mathrm{~mm} / \mathrm{yr}$ with an average pixel value of $-0.61 \mathrm{~mm} / \mathrm{yr}$ across the South tile. Several notable areas of localised subsidence were identified in the North tile that translated directly to several LSM sites registered in the Google Earth reference data. Areas of uplift generally fell over large stretches of Miombo woodland, recognised in the Google Earth reference data. The respective standard errors range from $0.35 \mathrm{~mm} / \mathrm{yr}$ to $1.54 \mathrm{~mm} / \mathrm{yr}$ with an average of $0.96 \mathrm{~mm} / \mathrm{yr}$ across the North tile, and $0.36 \mathrm{~mm} / \mathrm{yr}$ to $1.64 \mathrm{~mm} / \mathrm{yr}$ with an average of $1.05 \mathrm{~mm} / \mathrm{yr}$ across the South tile. Over large mining areas, the standard error is very low due to the high number of coherent pixels per point over the bare/rocky land cover. 


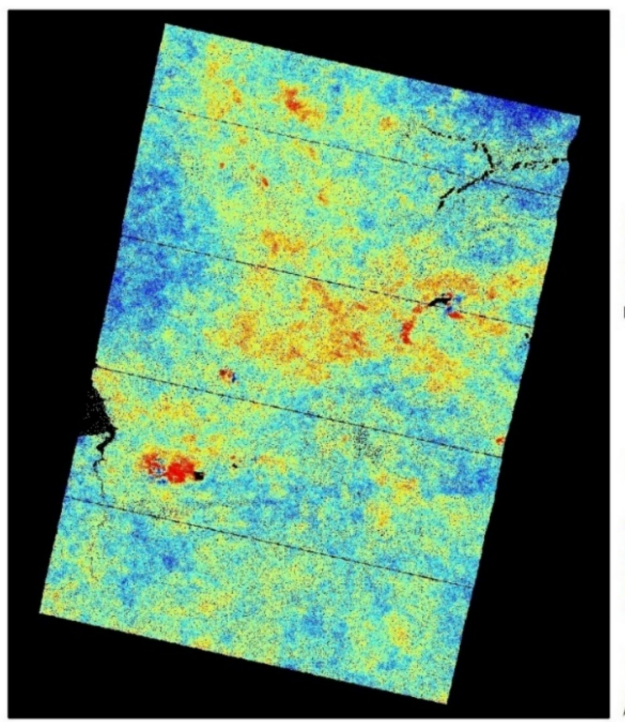

North Tile:
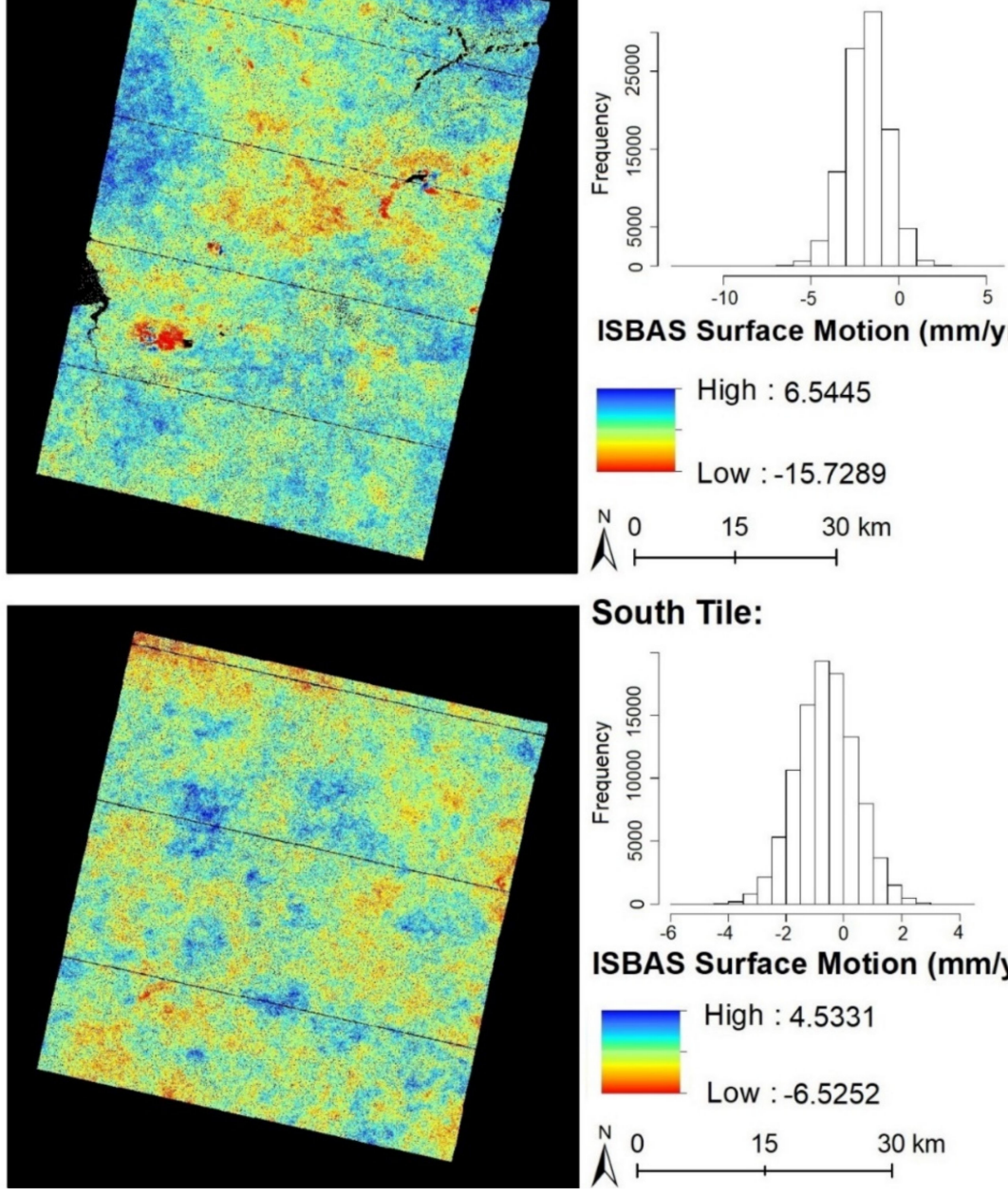

ISBAS Surface Motion (mm/yr)

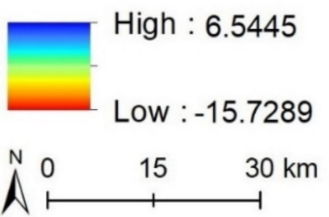

South Tile:

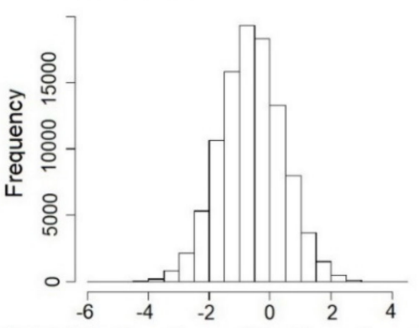

ISBAS Surface Motion (mm/yr)

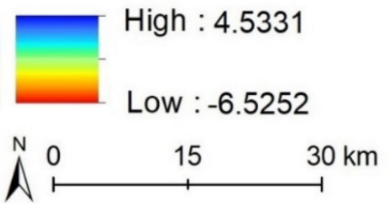

Figure 4. Sentinel-1 derived ISBAS surface motion (mm/yr) map outputs and histogram for North and South tile. Negative values indicate subsidence and positive values uplift.

\subsection{Mine Identification}

Within the defined study area, 215 mining locations were identified, digitised (polygon created), and categorised by mine type (industrial, surface, and tunnel) in the Google Earth platform (Table 5).

Table 5. Results from the Google Earth mine identification and polygon digitisation.

\begin{tabular}{ccccc}
\hline Mine Type & Number & Mean Area $\left.\mathbf{( m}^{\mathbf{2}}\right)$ & Minimum Area $\left.\mathbf{( m}^{\mathbf{2}}\right)$ & Maximum Area $\mathbf{( m}^{\mathbf{2}} \mathbf{)}$ \\
\hline Industrial & 48 & $512,309.02$ & 5002 & $2,213,418$ \\
Surface & 100 & $374,595.02$ & 1166 & $17,658,728$ \\
Tunnel & 67 & $59,514.82$ & 411 & 458,686 \\
\hline
\end{tabular}

A limitation of this approach is the availability of VHR data on the Google Earth platform, both in terms of area and temporal coverage. It was noted during the visual search that a higher volume of VHR data was found in areas where LSM was located. Additionally, error might be introduced from the researcher's bias in the visual interpretation of a mining site and/or type. However, expertise and guidance from extensive fieldwork in the DRC's Copperbelt reduces the potential error in mine identification and provides confidence in our results. 


\subsection{Statistical Analysis}

A significant difference between mine and non-mine polygons was found for all descriptive variables derived from the ISBAS outputs: mean ( $\mathrm{W}=3361$, d.f. $=1, p$-value $=<0.001)$, standard deviation $(\mathrm{W}=15792$, d.f. $=1$, $p$-value $=<0.001)$, minimum $(\mathrm{W}=4025$, d.f. $=1$, $p$-value $=<0.001)$, and maximum $(\mathrm{W}=7238$, d.f. $=1$, $p$-value $=<0.001)($ Table 6, Figure 5).

Table 6. Median and interquartile range (IQR) values for the mine and non-mine ISBAS descriptive variables (mean, standard deviation, minimum, and maximum).

\begin{tabular}{ccccccccc}
\hline \multirow{2}{*}{ Mine/Non-Mine } & \multicolumn{2}{c}{ Mean } & \multicolumn{2}{c}{ Standard Deviation } & \multicolumn{2}{c}{ Minimum } & \multicolumn{2}{c}{ Maximum } \\
& Median & IQR & Median & IQR & Median & IQR & Median & IQR \\
\hline Mine & -2.33 & 1.72 & 0.93 & 0.49 & -4.64 & 3.20 & -0.05 & 1.63 \\
Non-Mine & -1.13 & 0.81 & 0.79 & 0.16 & -2.67 & 1.59 & 0.65 & 0.90 \\
\hline
\end{tabular}
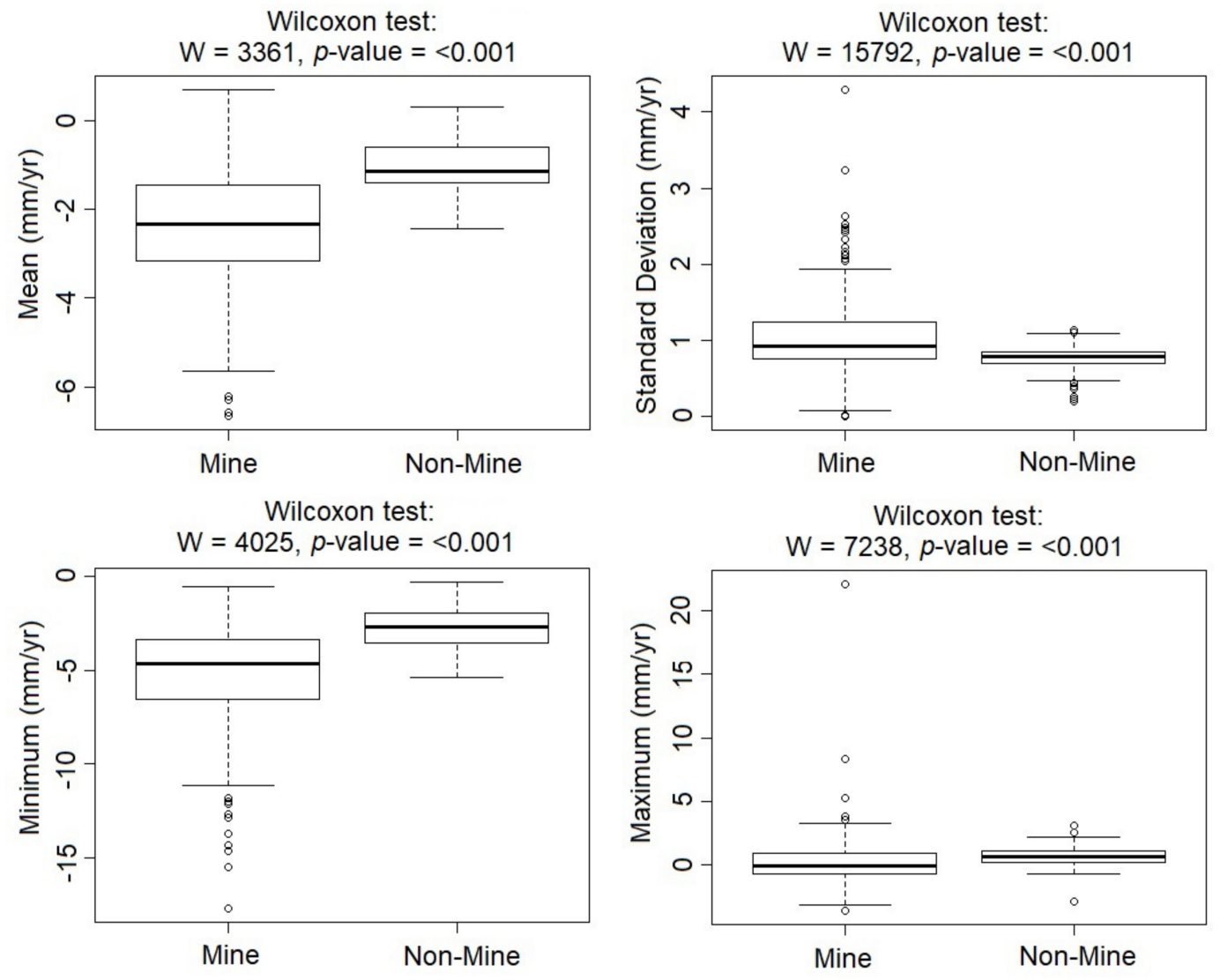

Figure 5. Wilcoxon test results and boxplots for mine and non-mine descriptive variables (mean, standard deviation, minimum, and maximum).

A significant difference between mine type (industrial, surface, and tunnels) was found for the descriptive variables mean (Kruskal-Wallis: Chi-square $=29.93, \mathrm{df}=2, p$-value $=<0.001$ ), standard deviation (Kruskal-Wallis: Chi-square $=41.68, \mathrm{df}=2, p$-value $=<0.001$ ) and minimum (Kruskal-Wallis: Chi-square $=64.74, \mathrm{df}=2, p$-value $=<0.001$ ) (Table 7, Figure 6). No significant difference was found between mine type (industrial, surface, and tunnels) for maximum polygon value (Kruskal-Wallis: Chi-square $=2.97, \mathrm{df}=2, p$-value $=0.23)($ Table 7 , Figure 6) . 
Table 7. Median and interquartile range (IQR) values for the different mine type ISBAS descriptive variables (mean, standard deviation, minimum, and maximum).

\begin{tabular}{ccccccccc}
\hline \multirow{2}{*}{ Mine Type } & \multicolumn{2}{c}{ Mean } & \multicolumn{2}{c}{ Standard Deviation } & \multicolumn{2}{c}{ Minimum } & \multicolumn{2}{c}{ Maximum } \\
& Median & IQR & Median & IQR & Median & IQR & Median & IQR \\
\hline Industrial & $-3.02^{\mathrm{ab}}$ & 2.35 & $1.41^{\mathrm{de}}$ & 0.88 & $-7.16^{\mathrm{gh}}$ & 4.52 & 0.26 & 2.11 \\
Surface & $-2.52^{\mathrm{ac}}$ & 1.50 & $0.92^{\mathrm{df}}$ & 0.42 & $-4.94^{\mathrm{gi}}$ & 2.54 & -0.12 & 1.58 \\
Tunnel & $-1.75^{\mathrm{bc}}$ & 1.19 & $0.83^{\mathrm{ef}}$ & 0.31 & $-3.27^{\mathrm{hi}}$ & 1.62 & -0.07 & 1.45 \\
\hline
\end{tabular}

Significant pairwise Wilcoxon tests with Bonferroni adjustments share the same subscript letter.

Kruskal-Wallis test:

Chi-square $=29.93$, -value $=<0.001$

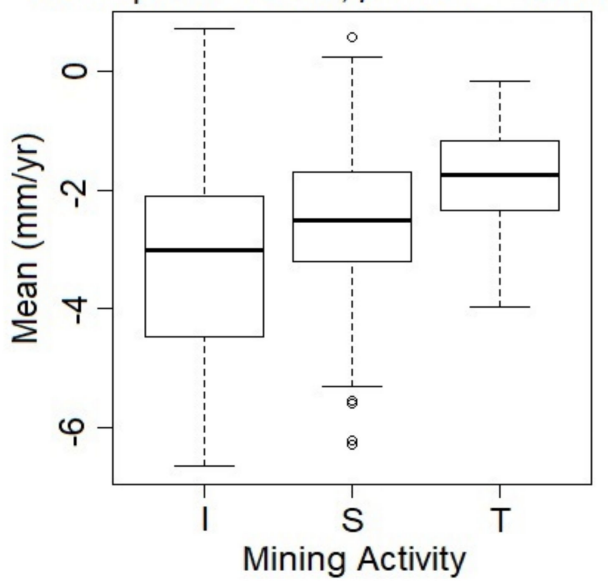

Kruskal-Wallis test:

Chi-square $=64.74, p$-value $=<0.001$

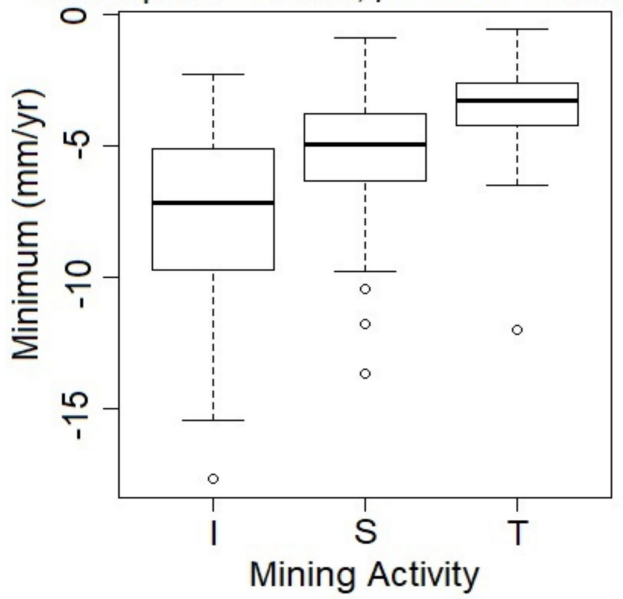

Kruskal-Wallis test:

Chi-square $=41.68, p$-value $=<0.001$

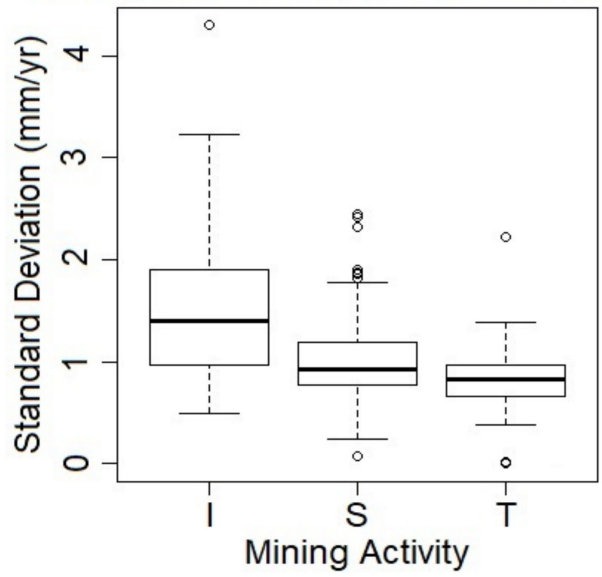

Kruskal-Wallis test: Chi-square $=2.97, p$-value $=0.23$

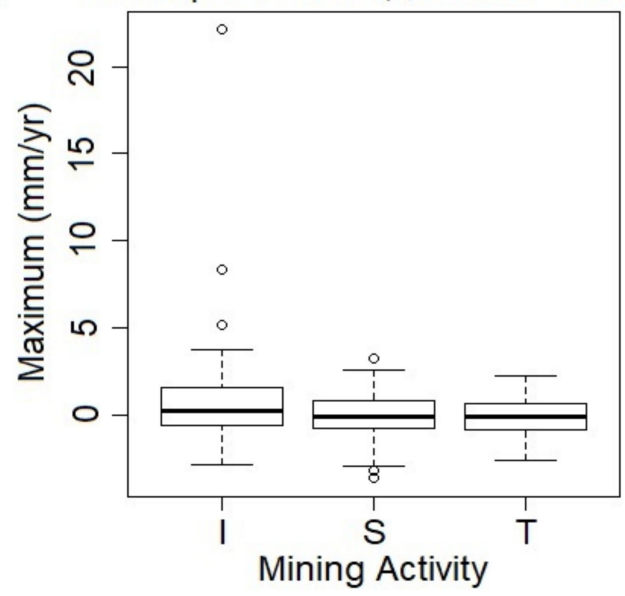

Figure 6. Kruskal-Wallis test results and boxplots for the different mine type descriptive variables (mean, standard deviation, minimum, and maximum). I = Industrial mines, S = Surface mines, and $\mathrm{T}=$ Tunnel mines.

\subsection{ASM Activity}

Given a significant difference was found between mine and non-mine locations for the descriptive variables, indicators of ASM activity were explored. Subsidence measured by ISBAS (i.e., a negative ISBAS pixel value) is a clear marker of mining activity [46], the descriptive variables mean and minimum were selected to trial further analysis as they present clear information on subsidence levels within the polygons. Conservative activity thresholds were set at the minimum recorded value of non-mining polygons for the descriptive variables mean and minimum (Figure 7). Under these conditions, an activity 
threshold was set at $-2.43 \mathrm{~mm} / \mathrm{yr}$ for mean ISBAS polygon values and $-5.36 \mathrm{~mm} / \mathrm{yr}$ for minimum ISBAS polygon values.

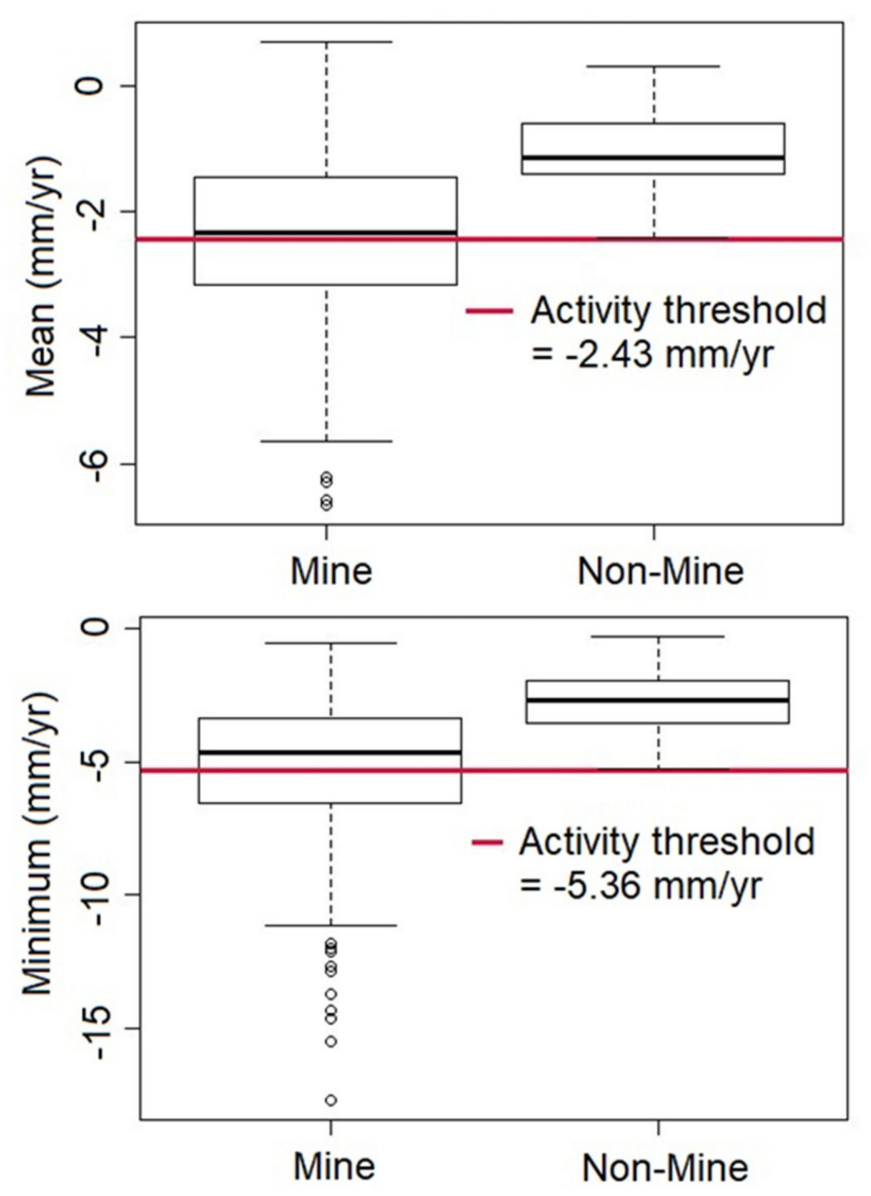

Figure 7. Boxplots presenting data on the descriptive variables mean and minimum for mine and non-mine polygons. The red line indicates activity threshold set as the minimum recorded value for non-mine polygons.

The activity threshold set for mean ISBAS polygon values registered 54 surface mine and 14 tunnel mine sites as active. The activity threshold set for minimum ISBAS polygon values registered 40 surface mine and 10 tunnel mine sites as active. A total of 32 surface mine and 6 tunnel mine locations were registered as active in both the mean and minimum ISBAS polygon scenarios. Figure 8 presents an example of a surface mine site registered as active, and Figure 9 shows an example of a tunnel mine site registered as active. No ground data was available to validate the results. Google Earth was used as a reference data source to compare with the active ASM identification results. Comparison of the datasets found that the large, long-standing ASM sites were identified as active within the study time frame 6/3/2017 to $26 / 1 / 2020$. The results suggest that smaller, more exploratory mining was not accounted for under the strict activity thresholds. 


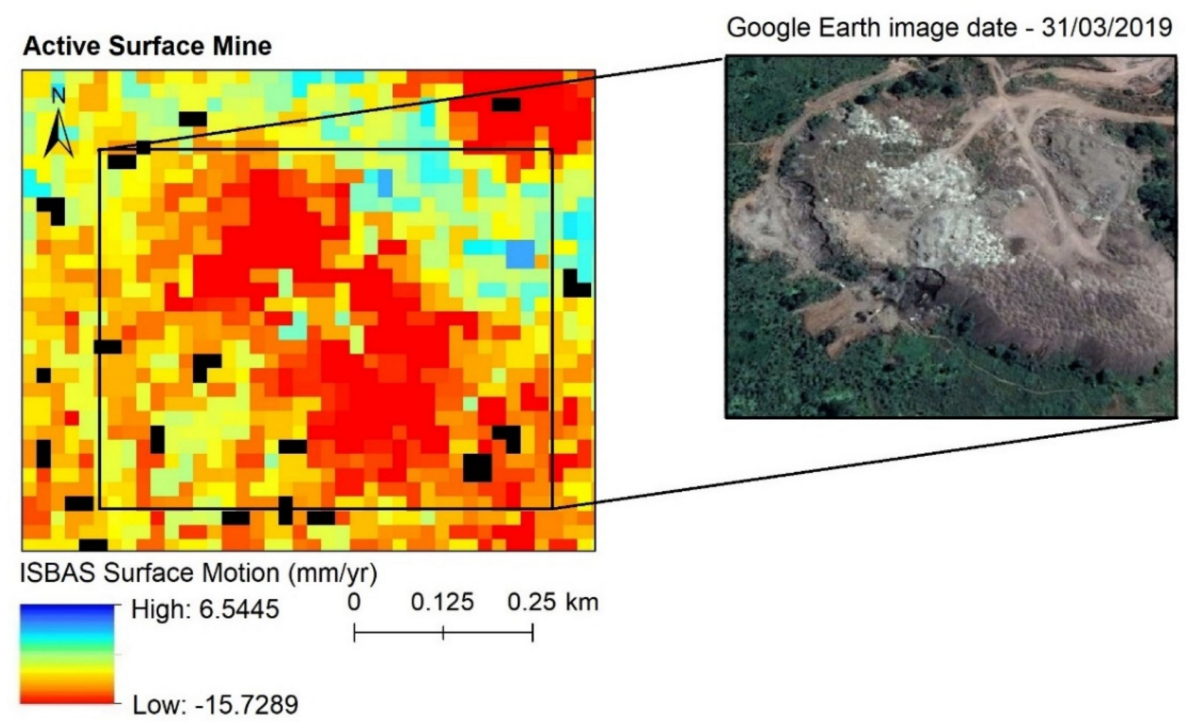

Figure 8. Sentinel-1 ISBAS surface motion (mm/yr) map output over an area identified as an active surface mine (black pixel $=$ NA values). Corresponding Google Earth very high resolution (VHR) imagery over the same area presented to aid in the interpretation of the results.

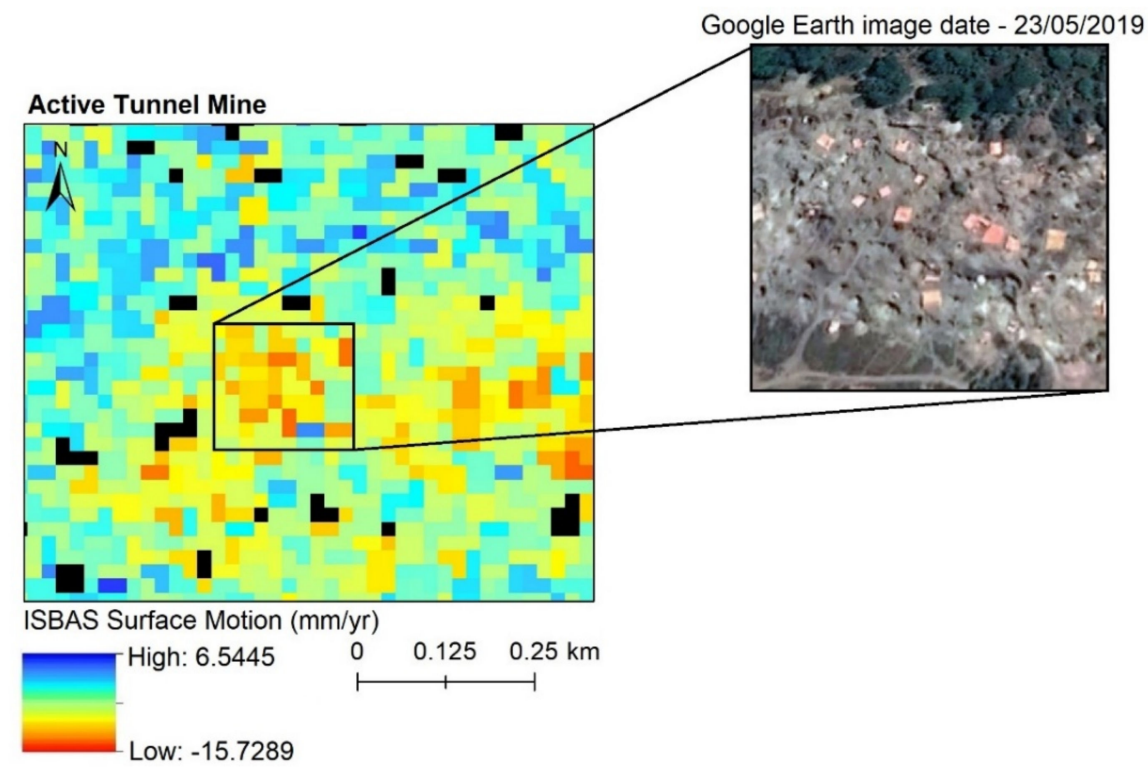

Figure 9. Sentinel-1 ISBAS surface motion ( $\mathrm{mm} / \mathrm{yr})$ map output over an area identified as an active tunnel mine (black pixel = NA values). Corresponding Google Earth VHR imagery over the same area presented to aid in the interpretation of the results.

\section{Discussion}

Rechargeable, lithium-ion batteries are a key component in global efforts to move towards green technology and reduce fossil fuel dependency (SDG 7: Affordable and Clean Energy and SDG 13: Climate Action) [59]. However, cobalt miners in the DRC, who extract the cobalt needed for these batteries, do not benefit from this positive environmental movement in green technology. Instead, vulnerable mining communities are faced with increasing human rights violations, child labour exploitation, hazardous working conditions, environmental degradation, and health risks. EO provides a practical and affordable approach to mapping ASM in rural settings, supplying data that is urgently required to build confidence in ASM figures and estimations, and support the development of rigorous monitoring systems. 
This study sought to answer the question, can the ISBAS approach be used to identify active areas of ASM in a rural landscape? To the best of our knowledge, this is the first use of the ISBAS method for tracking activity in cobalt mining and the first example of surface motion outputs over the Copperbelt region. Statistical analyses of surface motion outputs explored the feasibility of the ISBAS approach for identifying active ASM in rural locations, and thus demonstrated its potential in future ASM monitoring systems. A significant difference was found for the ISBAS descriptive variables between mine and non-mine polygons (Table 6, Figure 5). These are encouraging results given the low coherence issues associated with a mountainous rural landscape. Land surface motion can be highly variable as a result of rural vegetation change, by both natural and human processes [60]. This is further heightened by the intense seasonality of the DRC's tropical climate, especially in rainfall. The influence of rural vegetation in this setting can create noisy data and limit meaningful visual interpretation of outputs. Figure 5 presents data for the ISBAS descriptive variables for mine and non-mine polygons. In general, descriptive variables for mine polygons have a larger range of values between the highest and lowest observations, and in the interquartile range, compared with non-mine polygons. Standard deviation $(\mathrm{mm} / \mathrm{yr})$ values for mine polygons vary widely, which indicates that pixel values within the polygons are not uniform. This could be reflective of mining locations where pixels relating to subsidence from material extraction and pixels relating to uplift from waste material pilling, sit within the same polygon area, or of large mining complexes where not all pixels in the polygon are being actively mined (for example infrastructure development in LSM). The mean ( $\mathrm{mm} / \mathrm{yr}$ ) and minimum $(\mathrm{mm} / \mathrm{yr})$ descriptive variables both reported low median and lowest observed values for mine polygons, presenting clear evidence of subsidence.

As well as areas of mining and non-mining reporting significantly different values for the descriptive variables, the ISBAS data could be further separated into mine type (industrial, surface, and tunnels). A significant difference was found for the ISBAS descriptive variables mean, standard deviation, and minimum between the different mine types (industrial, surface, and tunnels) (Table 7, Figure 6). No significant difference was found for the maximum ISBAS polygon values between the different mine types (industrial, surface, and tunnels) (Table 7, Figure 6). Mine type is determined by the cobalt deposit. The DRC features two distinct deposit types: weathered oxide deposits, which are aboveground, near-surface deposits; and un-weathered sulphide deposits, which are underground deposits [61]. ASM practices can be found in both deposit types, surface mining in weathered oxide, and tunnel mining in weathered oxide and un-weathered sulphide. Surface mining practices in the Copperbelt are fairly unusual in that they can operate in both natural and artificial deposits created by industrial mining waste or tailings. This duality has led to increased tension and violence from the authorities and neighbouring LSM operators [62]. Tunneling is a high-risk, high-reward activity. Tunnel exploration of deep cobalt deposits are attached to the greatest safety risks (and fatalities), for example, underground explosions, tunnel collapse, and suffocation due to poor ventilation $[63,64]$.

Tunnel mining reported the highest median values for the descriptive variables that indicate subsidence (mean and minimum) for mine polygons (Table 7, Figure 6). The following discussion will try to understand these results in the context of the Copperbelt mining landscape and the time frame of the study. The tunnel mine polygons identified and digitised in Google Earth were notably smaller in size compared with the industrial and surface (Table 5), with a mean area size of $59514.82 \mathrm{~m}^{2}(6 \mathrm{x}$ smaller than mean surface mine area and $8 x$ smaller than mean industrial mine area). The smallest area reported for a tunnel polygon was $411 \mathrm{~m}^{2}$. This small area size could cause low feature spatial accuracies when extracting polygon data from the ISBAS outputs, as a result of pixel and feature size similarities. The ISBAS outputs have a $20 \mathrm{~m}$ spatial resolution which equates to a pixel area of $400 \mathrm{~m}^{2}$. The smaller size of the tunnel polygons is linked to the exploratory nature of this cobalt mining type. Single tunnels are dug with the goal to discover a mineral deposit; if a cobalt vein is not hit or profitable, the tunnel is abandoned. Where viable mineral deposits are found, hundreds of tunnel mines can be excavating simultaneously at one location, often with no coordination or knowledge of previous 
operations. High volumes of tunnel activity can produce complex surface motion patterns, with vertical and horizontal digging, and alterations in the water table (via water pumps) impacting the results we see in the ISBAS outputs. Seasonality adds another layer of complexity when interpreting ISBAS results for tunnel mines over the study time period (6/3/2017 to 26/1/2020). Tunnel flooding and increased risk of rock instability in the rainy season means the closure of many mines [65], particularly in cases with minimal structural support or the use of a water pump [10].

Additionally, the resumption of subsistence agriculture activities (based on seasons) can dramatically alter the monthly activity of tunnel mines over the course of a year. Seasonal fluctuations will impact the interpretation of ISBAS outputs; further work needs to be made to understand the magnitude of short-term seasonal effects relative to long term trends in ASM activity. For example, future work could focus on processing SAR data captured in the dry season (May-October) only. Under these processing conditions, we expect subsidence levels to be greater (i.e., a lower median value for the mean and minimum descriptive variables) in tunnel mine polygons; this approach could potentially produce more accurate and reliable data to build an ASM monitoring system from.

The ISBAS method is an effective means of monitoring land subsidence at landscape scales. By setting activity thresholds the concept of using ISBAS outputs to identify active ASM was explored. This trial set two activity thresholds, one at $-2.43 \mathrm{~mm} / \mathrm{yr}$ for mean ISBAS polygon values, and one at $-5.36 \mathrm{~mm} / \mathrm{yr}$ for minimum ISBAS polygon values. The number of surface and tunnel mines identified as active under the two different thresholds varied, with 32 surface mine and 6 tunnel mine polygons registered as active under both restrictions. The activity thresholds were set at very strict values as no ground data was collected to support or validate the results. As a result, the strict thresholds likely underreport the actual number of active surface and tunnel mines present in the study area during the time period $6 / 3 / 2017$ to $26 / 1 / 2020$. This underrepresentation is further heightened by the seasonality of ASM, as previously discussed. Future research should re-evaluate these thresholds with further ISBAS processing in dry-season months only, teamed with accurate ground data of active and non-active ASM locations. In answer to the study's overall question, the ISBAS method has real potential as an approach to identify active areas of ASM in a rural landscape. However, the method needs to be further developed and educated with a greater understanding of the complex physical processes and interactions of ASM and the wider rural Copperbelt landscape before a definitive conclusion can be made.

Advocacy for the application of the ISBAS method for ASM activity monitoring is supported by the recent expansion of satellite SAR imaging sensor technology. Satellite SAR sensors, such as that on-board the Sentinel-1 constellation, are the only spaceborne technology able to record high-resolution imagery, on a global scale, independent of light or weather conditions [66]. The short repeat cycle of the Sentinel-1 constellation-12-day repeat over most of the world's land surface-provides the high volume of SAR data required for ISBAS processing. The twin satellite constellation was launched in part, Sentinel-1A in 2014 and Sentinel-1B in 2016, access to archived Sentinel-1 data means it is possible to investigate past ASM activity. Exploring surface motion patterns before the boom in cobalt demand (2016) or narrowing down timelines to peak production years can all be explored with this rich data reserve.

The SDGs were created to remove people from poverty, protect the environment, and ensure equality, peace, and prosperity for all. The 17 SDGs, by their very nature, are interconnected [67]. Actions designed to meet one goal should not directly or indirectly jeopardise the achievement of another. Responsible and sustainable sourcing of cobalt relies on end-user companies engaging with and challenging human rights and corruption risks throughout their supply chains $[9,68,69]$. Only sourcing cobalt from LSM is not a viable means to remove risk from supply chains, due to links with corruption and the illicit blending of ASM outputs with those of LSM. Companies who decide to disengage with ASM should also take into account the adverse consequences to the local livelihoods of vulnerable communities. Resources, such as those outlined in this study, are required to better understand the influence and future role of ASM in the DRC's cobalt mining sector. 


\section{Conclusions}

This study examined the feasibility of the ISBAS method, teamed with high-frequency Sentinel-1 SAR imagery, for monitoring ASM activity in rural locations of the "Copperbelt", the DRC. ISBAS surface motion values were found to be significantly different between mining and non-mining areas, and could be used to further distinguish the different mine types (industrial, surface, and tunnel). A high level of subsidence (i.e., negative ISBAS pixel value) is a clear indicator of mine activity. With this in mind, activity thresholds were set for the descriptive variables mean $(-2.43 \mathrm{~mm} / \mathrm{yr})$ and minimum $(-5.36 \mathrm{~mm} / \mathrm{yr})$ to trial an ISBAS approach to active mine identification. Lack of ground data limited our ability to validate results; however, it was recognised that the large, long-standing ASM sites, registered in the Google Earth reference data, were identified as active within the study time frame. Ground data collection and further development of ISBAS analysis need to be made to fully understand the value of an ISBAS-based ASM monitoring system. In particular, there needs to be a greater awareness of the impact of seasonality relative to longer-term trends in ASM activity. Sentinel-1's global coverage and frequent repeat cycle represents an opportunity to develop the concepts presented in this study further. Such developments could see the upscale of ISBAS surface motion mapping across the entire Copperbelt region, providing strategic resources to help support the regulation and monitoring of cobalt ASM activity. Beyond this, since the use of radar interferometry is established in the mining sector, the ISBAS method has considerable potential in supporting ASM research of other "green conflict minerals". Global efforts to transition into more sustainable and resilient societies require an approach that recognises the interconnections between the SDGs. Responsible and sustainable sourcing of cobalt is an essential component for successfully meeting SDG 7: Affordable and Clean Energy and SDG 13: Climate Action, while simultaneously benefiting SDG 8: Decent Work and Economic Growth and SDG 16: Peace, Justice and Strong Institutions.

Author Contributions: C.B., A.D., and D.S.B. constructed and designed the concept for the paper, with C.B. and A.D. preforming data analyses. The ISBAS algorithm was implemented using Terra Motion Limited's in-house Punnet software, access to which may be granted by A.S. on reasonable request. S.K. provided expert knowledge of cobalt mining in the DRC and ground intelligence to inform mine identification. Writing was predominantly undertaken by C.B. with input from D.S.B., A.D., and G.F. All authors have read and agreed to the published version of the manuscript.

Funding: This work was supported by the Engineering and Physical Sciences Research Council [EP/S023577/1].

Acknowledgments: The authors would like to thank the Rights Lab at the University of Nottingham, Terra Motion Limited for InSAR data processing and Google Earth and ESA for making data openly accessible.

Conflicts of Interest: The authors declare no conflict of interest.

\section{References}

1. Financial Times. Dozens Die on Congo Mine Accident. Available online: https://www.ft.com/content/aea51 eb0-98c7-11e9-8cfb-30c211dcd229 (accessed on 25 October 2019).

2. Financial Times. Congo, Child Labour and Your Electric Car. Available online: https://www.ft.com/content/c 6909812-9ce4-11e9-9c06-a4640c9feebb (accessed on 25 October 2019).

3. Financial Times. Glencore in New Cobalt Supply Deal with South Korean Battery Maker. Available online: https://www.ft.com/content/9413aeaa-16b1-11ea-9ee4-11f260415385 (accessed on 16 February 2020).

4. The Wall Street Journal. Despite Cleanup Vows, Smartphones and Electric Cars Still Keep Miners Digging by Hand in Congo. Available online: https://www.wsj.com/articles/smartphones-electric-cars-keep-miners-dig ging-by-hand-in-congo-1536835334 (accessed on 27 October 2019).

5. CNN. CNN Discovers Child Labor in Cobalt Trade. Available online: https://edition.cnn.com/videos/world /2018/05/02/cnn-freedom-project-electric-cars-cobalt-elbagir-pkg.cnn (accessed on 25 October 2019).

6. Walt, V.; Meyer, S. Blood, Sweat, and Batteries. Available online: https://pulitzercenter.org/reporting/blood-s weat-and-batteries (accessed on 27 October 2019). 
7. Amnesty International. Time to Recharge: Corporate Action and Inaction to Tackle Abuses in the Cobalt Supply Chain. Available online: https://www.amnesty.org/en/documents/afr62/7395/2017/en/ (accessed on 10 January 2020).

8. Church, C.; Crawford, A. Green Conflict Minerals: The Fuels of Conflict in the Transition to a Low-Carbon Economy: IISD Report. International Institute for Sustainable Development. Available online: https://www. iisd.org/publications/green-conflict-minerals-fuels-conflict-transition-low-carbon-economy (accessed on 2 May 2020).

9. OECD. Interconnected Supply Chains: A Comprehensive Look at Due Diligence Challenges and Opportunities SOURCING Cobalt and Copper from the Democratic Republic of the Congo. Available online: https://mneguidelines.oecd.org/interconnected-supply-chains-a-comprehensive-look-atdue-diligence-challenges-and-opportunities-sourcing-cobalt-and-copper-from-the-drc.htm (accessed on 10 January 2020).

10. Bundesanstalt für Geowissenschaften und Rohstoffe. Mapping of the Artisanal Cobalt Mining Sector in the Provinces of Haut-Katanga and Lualaba in the Democratic Republic of the Congo. Available online: https://www.bgr.bund.de/EN/Themen/Min_rohstoffe/Downloads/studie_BGR_kupfer_kob alt_kongo_2019_en.html (accessed on 10 January 2020).

11. Faber, B.; Krause, B.; Sánchez de la Sierra, R. Artisanal Mining, Livelihoods, and Child Labor in the Cobalt Supply Chain of the Democratic Republic of Congo. Centre for Effective Global Action Policy Report. Available online: https://escholarship.org/uc/item/17m9g4wm (accessed on 7 April 2020).

12. O'Driscoll, D. Overview of Child Labor in the Artisanal and Small-Scale Mining Sector in Asia and Africa. Available online: https://assets.publishing.service.gov.uk/media/5a5f34feed915d7dfb57d02f/209-213-Child-la bour-in-mining.pdf (accessed on 16 February 2020).

13. Amnesty International. "This is what We Die For": Human Rights Abuses in the Democratic Republic of the Congo Power the Global Trade in Cobalt. Available online: https://www.amnesty.org/en/documents/afr 62/3183/2016/en/ (accessed on 25 October 2019).

14. Bannock Consulting. Vulnerability of Artisanal and Small-Scale Mining to Commodity Price Fluctuation. Available online: https://assets.publishing.service.gov.uk/media/57a08c9640f0b652dd00140e/C40PAPER5.pdf (accessed on 5 May 2020).

15. Guardian. "Is your phone Tainted by the Misery of the 35,000 Children in Congo's Mines?". Available online: https://www.theguardian.com/global-development/2018/oct/12/phone-misery-children-con go-cobalt-mines-drc (accessed on 14 August 2019).

16. Transport \& Environment. Cobalt from Congo: How to Source it Better. Comparative Analysis of Existing Supply Chain Certification Schemes and Artisanal Practices. Available online: https://www.transportenvironment.org/sit es/te/files/publications/Cobalt\%20from\%20Congo_how\%20to\%20source\%20it\%20better_Final.pdf (accessed on 10 January 2020).

17. Davies, D. Restrictions on Sourcing of Cobalt are Changing. Available online: https://www.pv-magazine.co m/2020/03/10/restrictions-on-sourcing-of-cobalt-are-changing/ (accessed on 7 April 2020).

18. International Rights Advocates (Attorneys for Plaintiffs) v Apple Inc., Alphabet Inc., Dell Inc., Microsoft Inc., and Tesla. United States District Court for the District of Columbia, Case 1:19-cv-03737. Filed 12/15/19. Available online: http://iradvocates.org/sites/iradvocates.org/files/stamped\%20-Complaint.pdf (accessed on 29 May 2020).

19. Financial Times. China's Top Cobalt Producer Halts Buying from Congo Miners. Available online: https://www.ft.com/content/ce9af944-fb70-4576-88d0-dc76821facfd (accessed on 29 May 2020).

20. Reuters. Column: Congo's Move to Control Artisanal Cobalt is Double-Edged. Available online: https:/uk.reuters.com/article/uk-cobalt-congo-ahome/column-congos-move-to-control-artisanal-cobalt-is -double-edged-idUKKBN2011HE (accessed on 29 May 2020).

21. Freedom United. The Democratic Republic of Congo's Bid to Stamp out Child Labor in Cobalt Sector. Available online: https://www.freedomunited.org/news/congos-bid-to-stamp-out-child-labor-in-cobalt-sec tor/ (accessed on 7 April 2020).

22. Estoque, R.C. A Review of the Sustainability Concept and the State of SDG Monitoring Using Remote Sensing. Remote Sens. 2020, 12, 1770. [CrossRef] 
23. Giuliani, G.; Mazzetti, P.; Santoro, M.; Nativi, S.; Van Bemmelen, J.; Colangeli, G.; Lehmann, A. Knowledge generation using satellite earth observations to support sustainable development goals (SDG): A use case on Land degradation. Int. J. Appl. Earth Obs. Geoinf. 2020, 88, 102068. [CrossRef]

24. Anderson, K.; Ryan, B.; Sonntag, W.; Kavvada, A.; Friedl, L. Earth observation in service of the 2030 Agenda for Sustainable Development. Geo-Spat. Inf. Sci. 2017, 20, 77-96. [CrossRef]

25. Foody, G.M.; Ling, F.; Boyd, D.S.; Li, X.; Wardlaw, J. Earth observation and machine learning to meet Sustainable Development Goal 8.7: Mapping sites associated with slavery from space. Remote Sens. 2019, 11, 266. [CrossRef]

26. Brown, D.; Boyd, D.S.; Brickell, K.; Ives, C.D.; Natarajan, N.; Parsons, L. Modern slavery, environmental degradation and climate change: Fisheries, field, forests and factories. Environ. Plan. Nat. Space 2019. [CrossRef]

27. Jackson, B.; Bales, K.; Owen, S.; Wardlaw, J.; Boyd, D.S. Analysing slavery through satellite technology: How remote sensing could revolutionise data collection to help end modern slavery. J. Mod. Slavery 2018, 4, 169-199.

28. Boyd, D.S.; Jackson, B.; Wardlaw, J.; Foody, G.M.; Marsh, S.; Bales, K. Slavery from space: Demonstrating the role for satellite remote sensing to inform evidence-based action related to UN SDG number 8. ISPRS J. Photogramm. Remote Sens. 2018, 142, 380-388. [CrossRef]

29. Rosen, P.A.; Hensley, S.; Joughin, I.R.; Li, F.K.; Madsen, S.N.; Rodriguez, E.; Goldstein, R.M. Synthetic aperture radar interferometry. Proc. IEEE 2000, 88, 333-382. [CrossRef]

30. Massonnet, D.; Feigl, K.L. Radar interferometry and its application to changes in the Earth's surface. Rev. Geophys. 1998, 36, 441-500. [CrossRef]

31. Yang, Z.; Li, Z.; Zhu, J.; Yi, H.; Hu, J.; Feng, G. Deriving dynamic subsidence of coal mining areas using InSAR and logistic model. Remote Sens. 2017, 9, 125. [CrossRef]

32. Ng, A.H.M.; Ge, L.; Zhang, K.; Chang, H.C.; Li, X.; Rizos, C.; Omura, M. Deformation mapping in three dimensions for underground mining using InSAR-Southern highland coalfield in New South Wales, Australia. Int. J. Remote Sens. 2011, 32, 7227-7256. [CrossRef]

33. Perski, Z.; Hanssen, R.; Wojcik, A.; Wojciechowski, T. InSAR analyses of terrain deformation near the Wieliczka Salt Mine, Poland. Eng. Geol. 2009, 106, 58-67. [CrossRef]

34. Yuan, W.; Wang, Q.; Fan, J.; Li, H. Mining land subsidence monitoring using Sentinel-1 SAR data. International Archives of the Photogrammetry. Remote Sens. Spat. Inf. Sci. 2017, 42, 655-658.

35. Hu, Z.; Ge, L.; Li, X.; Zhang, K.; Zhang, L. An underground-mining detection system based on DInSAR. IEEE Trans. Geosci. Remote Sens. 2012, 51, 615-625. [CrossRef]

36. Sowter, A.; Bateson, L.; Strange, P.; Ambrose, K.; Syafiudin, M.F. DInSAR estimation of land motion using intermittent coherence with application to the South Derbyshire and Leicestershire coalfields. Remote Sens. Lett. 2013, 4, 979-987. [CrossRef]

37. Crosetto, M.; Monserrat, O.; Cuevas-González, M.; Devanthéry, N.; Crippa, B. Persistent scatterer interferometry: A review. ISPRS J. Photogramm. Remote Sens. 2016, 115, 78-89. [CrossRef]

38. Sowter, A.; Amat, M.B.C.; Cigna, F.; Marsh, S.; Athab, A.; Alshammari, L. Mexico City land subsidence in 2014-2015 with Sentinel-1 IW TOPS: Results using the Intermittent SBAS (ISBAS) technique. Int. J. Appl. Earth Obs. Geoinf. 2016, 52, 230-242. [CrossRef]

39. Grebby, S.; Orynbassarova, E.; Sowter, A.; Gee, D.; Athab, A. Delineating ground deformation over the Tengiz oil field, Kazakhstan, using the Intermittent SBAS (ISBAS) DInSAR algorithm. Int. J. Appl. Earth Obs. Geoinf. 2019, 81, 37-46. [CrossRef]

40. Gee, D.; Sowter, A.; Novellino, A.; Marsh, S.; Gluyas, J. Monitoring land motion due to natural gas extraction: Validation of the Intermittent SBAS (ISBAS) DInSAR algorithm over gas fields of North Holland, the Netherlands. Mar. Pet. Geol. 2016, 77, 1338-1354. [CrossRef]

41. Novellino, A.; Cigna, F.; Sowter, A.; Ramondini, M.; Calcaterra, D. Exploitation of the Intermittent SBAS (ISBAS) algorithm with COSMO-SkyMed data for landslide inventory mapping in north-western Sicily, Italy. Geomorphology 2017, 280, 153-166. [CrossRef]

42. Alshammari, L.; Boyd, D.S.; Sowter, A.; Marshall, C.; Andersen, R.; Gilbert, P.; Marsh, S.; Large, D.J. Use of Surface Motion Characteristics Determined by InSAR to Assess Peatland Condition. J. Geophys. Res. Biogeosci. 2020, 125, e2018JG004953. [CrossRef] 
43. Alshammari, L.; Large, D.J.; Boyd, D.S.; Sowter, A.; Anderson, R.; Andersen, R.; Marsh, S. Long-term peatland condition assessment via surface motion monitoring using the ISBAS DInSAR technique over the Flow Country, Scotland. Remote Sens. 2018, 10, 1103. [CrossRef]

44. Marshall, C.; Large, D.J.; Athab, A.; Evers, S.L.; Sowter, A.; Marsh, S.; Sjögersten, S. Monitoring tropical peat related settlement using isbas insar, kuala lumpur international airport (klia). Eng. Geol. 2018, 244, 57-65. [CrossRef]

45. Cigna, F.; Sowter, A. The relationship between intermittent coherence and precision of ISBAS InSAR ground motion velocities: ERS-1/2 case studies in the UK. Remote Sens. Environ. 2017, 202, 177-198. [CrossRef]

46. Gee, D.; Bateson, L.; Sowter, A.; Grebby, S.; Novellino, A.; Cigna, F.; Marsh, S.; Banton, C.; Wyatt, L. Ground motion in areas of abandoned mining: Application of the intermittent SBAS (ISBAS) to the Northumberland and Durham Coalfield, UK. Geosciences 2017, 7, 85. [CrossRef]

47. Bateson, L.; Cigna, F.; Boon, D.; Sowter, A. The application of the Intermittent SBAS (ISBAS) InSAR method to the South Wales Coalfield, UK. Int. J. Appl. Earth Obs. Geoinf. 2015, 34, 249-257. [CrossRef]

48. Novellino, A.; Athab, A.D.; bin Che Amat, M.A.; Syafiudin, M.F.; Sowter, A.; Marsh, S.; Cigna, F.; Bateson, L. Intermittent SBAS ground motion analysis in low seismicity areas: Case studies in the Lancashire and Staffordshire coalfields, UK. In Seismology from Space: Geodetic Observations and Early Warning of Earthquakes; Royal Astronomical Society: London, UK; Burlington House: London, UK, 2014.

49. Gee, D.; Bateson, L.; Grebby, S.; Novellino, A.; Sowter, A.; Wyatt, L.; Marsh, S.; Morgenstern, R.; Athab, A. Modelling groundwater rebound in recently abandoned coalfields using DInSAR. Remote Sens. Environ. 2020, 249, 112021. [CrossRef]

50. Wang, S.; Lu, X.; Chen, Z.; Zhang, G.; Ma, T.; Jia, P.; Li, B. Evaluating the Feasibility of illegal open-pit mining identification using insar coherence. Remote Sens. 2020, 12, 367. [CrossRef]

51. Choi-Fitzpatrick, A. The Good Drone: How Social Movements Democratize Surveillance. MIT Press 2020.

52. Andries, A.; Morse, S.; Murphy, R.J.; Lynch, J.; Woolliams, E.R. Seeing sustainability from space: Using Earth observation data to populate the UN Sustainable Development Goal indicators. Sustainability 2019, 11, 5062. [CrossRef]

53. Faucon, M.P.; Le Stradic, S.; Boisson, S.; wa Ilunga, E.I.; Séleck, M.; Lange, B.; Guillaume, D.; Shutcha, M.N.; Pourret, O.; Meerts, P.; et al. Implication of plant-soil relationships for conservation and restoration of copper-cobalt ecosystems. Plant Soil 2016, 403, 153-165. [CrossRef]

54. Syampungani, S.; Chirwa, P.W.; Akinnifesi, F.K.; Sileshi, G.; Ajayi, O.C. The miombo woodlands at the crossroads: Potential threats, sustainable livelihoods, policy gaps and challenges. Nat. Resour. Forum 2009, 33, 150-159. [CrossRef]

55. Gee, D.; Sowter, A.; Grebby, S.; de Lange, G.; Athab, A.; Marsh, S. National geohazards mapping in Europe: Interferometric analysis of the Netherlands. Eng. Geol. 2019, 256, 1-22. [CrossRef]

56. Farr, T.G.; Rosen, P.A.; Caro, E.; Crippen, R.; Duren, R.; Hensley, S.; Kobrick, M.; Paller, M.; Rodriguez, E.; Roth, L.; et al. The shuttle radar topography mission. Rev. Geophys. 2007, 45, 1-33. [CrossRef]

57. Chen, C.W.; Zebker, H.A. Two-dimensional phase unwrapping with use of statistical models for cost functions in nonlinear optimization. JOSA A 2001, 18, 338-351. [CrossRef]

58. Lesiv, M.; See, L.; Laso Bayas, J.C.; Sturn, T.; Schepaschenko, D.; Karner, M.; Moorthy, I.; McCallum, I.; Fritz, S. Characterizing the spatial and temporal availability of very high resolution satellite imagery in google earth and microsoft bing maps as a source of reference data. Land 2018, 7, 118. [CrossRef]

59. IISD SDG Knowledge Hub. Global Electric Vehicles Sales Surge, but Emissions from Transport Rise Faster. Available online: http://sdg.iisd.org/news/global-electric-vehicles-sales-surge-but-emissions-from-transpor t-rise-faster/ (accessed on 2 May 2020).

60. Ferretti, A.; Colesanti, C.; Perissin, D.; Prati, C.; Rocca, F. Evaluating the effect of the observation time on the distribution of SAR permanent scatterers. Proc. Fringe. 2003, 1-5.

61. Crundwell, F.K.; Moats, M.S.; Ramachandran, V.; Robinson, T.G.; Davenport, W.G. Production of cobalt from the copper-cobalt ores of the central african copperbelt. Extr. Metall. Nickel Cobalt Platin. Group Met. 2011, 1, 377-391.

62. Sovacool, B.K. The precarious political economy of cobalt: Balancing prosperity, poverty, and brutality in artisanal and industrial mining in the Democratic Republic of the Congo. Extr. Ind. Soc. 2019, 6, 915-939. [CrossRef] 
63. Lindberg, S.; Anderson, U. Blood Batteries, So High is the Price for the Technology of the Future. Available online: https://special.aftonbladet.se/blodsbatterier/ (accessed on 16 February 2020).

64. Elenge, M.M.; De Brouwer, C. Identification of hazards in the workplaces of artisanal mining in Katanga. Int. J. Occup. Med. Environ. Health 2011, 24, 57-66. [CrossRef]

65. Tsurukawa, N.; Prakash, S.; Manhart, A. Social Impacts of Artisanal Cobalt Mining in Katanga, Democratic Republic of Congo. Öko-Institut eV, Freiburg. Available online: https://pdfs.semanticscholar.org/8b56/d22b 7f68856322fc47121a429e7c72a73cc1.pdf (accessed on 13 June 2020).

66. Moreira, A. A golden age for spaceborne SAR systems. In Proceedings of the 20th International Conference on Microwaves, Radar and Wireless Communications, Gdansk, Poland, 16-18 June 2014; IEEE: Piscataway, NJ, USA, 2014; pp. 1-4.

67. Nilsson, M.; Griggs, D.; Visbeck, M. Map the interactions between Sustainable Development Goals. Nature 2016, 534, 320-322. [CrossRef] [PubMed]

68. Van den Brink, S.; Kleijn, R.; Sprecher, B.; Tukker, A. Identifying supply risks by mapping the cobalt supply chain. Resour. Conserv. Recycl. 2020, 156, 104743. [CrossRef]

69. Enough Project. Powering Down Corruption: Tackling Transparency and Human Rights Risks from Congo's Cobalt Mines to Global Supply Chains. Available online: https:/enoughproject.org/reports/powering-downcorruption (accessed on 2 May 2020).

Publisher's Note: MDPI stays neutral with regard to jurisdictional claims in published maps and institutional affiliations.

(C) 2020 by the authors. Licensee MDPI, Basel, Switzerland. This article is an open access article distributed under the terms and conditions of the Creative Commons Attribution (CC BY) license (http://creativecommons.org/licenses/by/4.0/). 